\title{
PENGGUNAAN ARANG AKTIF KULIT KACANG TANAH (Arachis hypogaea) SEBAGAI ADSORBEN DALAM PRODUKSI KAROTEN DARI FRAKSI OLEIN MINYAK SAWIT KASAR
}

\section{[The Use of Activated Charcoal Leather Peanut (Arachis hypogaea) as Adsorbent in The Production of Carotene from Crude Palm Oil Olein Fraction]}

\author{
Nurhaeni ${ }^{1^{\star}}$, Ni Ketut Sumarni ${ }^{1)}$, Eka Dwiyanti Tombilayuk ${ }^{1)}$ \\ 1) Jurusan Kimia FMIPA Universitas Tadulako, Palu \\ Jl. Soekarno Hatta Km.9, Kampus Bumi Tadulako Tondo Palu, Telp. 0451- 422611
}

Diterima 27 April 2016, Disetujui 11 Juni 2016

\begin{abstract}
Research using active charcoal leather peanut (Arachis hypogaea) as adsorbent in carotene production of crude palm oil olein fraction has conducted. This study aims to determine the ratio between active charcoal and olein that can produce the highest carotene shake time for 3 hours. Carotene analysis was conducted using UV-Vis spectrophotometry. The study design is applied is completely randomized design (CRD), with 5 variations adsorbent ratio is $1: 5 ; 1,5: 5 ; 2: 5 ; 2,5: 5 ; 3: 5$ $\mathrm{w} / \mathrm{v}$ and each stage is repeated twice. Results of this research showed that the ratio of peanut skin adsorbent 2: $5 \mathrm{w} / \mathrm{v}$ have the best adsorption weighing carotene obtained at $0,72 \mathrm{mg}$ and percent absorption by the adsorbent reaches $97,3 \%$.
\end{abstract}

Keywords: Peanut Leather, Adsorbents, UV-Vis spectrophotometry, Carotene.

\begin{abstract}
ABSTRAK
Telah dilakukan penelitian penggunaan arang aktif kulit kacang tanah (Arachis hypogaea) sebagai adsorben Dalam Produksi Karoten Dari Fraksi Olein Minyak Sawit Kasar. Penelitian ini bertujuan untuk mengetahui rasio antara arang aktif dan olein yang dapat menghasilkan karoten tertinggi dengan waktu pengocokkan selama 3 jam. Analisis karoten dilakukan dengan metode Spektrofotometri UV-Vis. Rancangan penelitian yang diterapkan adalah Rancangan Acak Lengkap (RAL), dengan 5 variasi rasio Adsorben yaitu $1: 5 ; 1,5: 5 ; 2: 5 ; 2,5: 5 ; 3: 5 \mathrm{~b} / \mathrm{v}$ dan masing- masing taraf diulang dua kali. Hasil penelitan ini menunjukan bahwa rasio adsorben kulit kacang tanah $2: 5 \mathrm{~b} / \mathrm{v}$ mempunyai adsorpsi terbaik dengan berat karoten yang diperoleh sebesar 0,72 $\mathrm{mg}$ dan persen penyerapan oleh adsorben mencapai $97,3 \%$.
\end{abstract}

Kata Kunci: Kulit Kacang Tanah, Adsorben, Spektrofotometri UV-Vis, Karoten. 


\section{LATAR BELAKANG}

Minyak sawit merupakan salah satu komoditas unggulan Indonesia yang pertumbuhannya sangat cepat dan mempunyai peran strategis dalam perekonomian nasional. Volume produksi minyak sawit Indonesia pada tahun 2014 diperkirakan mencapai 31,5 juta ton. Angka produksi tersebut meningkat 5\% dibandingkan total produksi pada tahun 2013 yang hanya mencapai 30 juta ton. Total ekspor CPO pada tahun 2014 mencapai 21,76 juta ton atau meningkat $2,5 \%$ dibandingkan dengan total ekspor 2013, yaitu 21,22 juta ton (GAPKI, 2015).

Produksi kelapa sawit di Sulawesi Tengah juga cukup besar. Berdasarkan data Direktorat Jendral Perkebunan Indonesia (2014), produksi kelapa sawit pada tahun 2014 mencapai 256.361 ton. Produksi ini meningkat dari tahun 2013 yang produksinya mencapai 244.074 ton. Salah satu keunggulan yang dimiliki minyak sawit yaitu tingginya kandungan karoten yang dimilikinya. Minyak sawit kasar memiliki kandungan karoten sekitar 500-700 ppm (Mustapa dkk., 2010). Komponen karotenoid pada minyak sawit memiliki banyak manfaat bagi kesehatan manusia. Selain sebagai pewarna alami, kandungan $\beta$-karoten dalam jumlah paling dominan menjadikan minyak sawit berfungsi sebagai provitamin $A$. Peranannya antara lain untuk penanggulangan kebutaan karena xerophtalmia (Muhilal, 1991), mencegah proses penuaan dini (May, 1994), mengurangi peluang terjadinya penyakit kanker dan penyakit degeneratif, serta meningkatkan imunitas tubuh (Iwasaki dan Murakoshi, 1992).

Beberapa metode telah dilakukan oleh peneliti dalam upaya pengambilan kembali karoten dalam minyak sawit kasar, antara lain metode saponifikasi, metode adsorpsi, metode kromatografi kolom adsorpsi. Metode adsorpsi atau metode penyerapan merupakan metode yang paling ekonomis diantara metode yang telah diterapkan. Kasimah (2013) menggunakan lempung sebagai adsorben pada produksi karoten dari fraksi olein minyak sawit. Diperoleh rasio terbaik yaitu 2,5:5 b/v dengan menghasilkan karoten $1,941 \mathrm{mg}$, dan waktu kontak terbaik yaitu pada waktu kontak 3 jam dengan kandungan karoten 1,307 mg.

Kulit kacang tanah merupakan salah satu jenis limbah pertanian kacang tanah yang dibuang begitu saja. Sejauh ini pemanfaatan kulit kacang tanah masih terbatas sebagai makanan ternak, padahal kulit kacang tanah mempunyai potensi menjadi adsorben karena mengandung selulosa yang cukup tinggi. Menurut Werdiono (2006), kandungan selulosa pada kulit kacang tanah sebesar $63,5 \%$.

Beberapa peneliti telah menggunakan arang kulit kacang tanah sebagai adsorben yang aplikasinya hanya sebagai penyerap zat warna limbah industri, arang briket dan asap cair, tetapi belum ada penelitian yang memanfaatkan arang aktif kulit kacang tanah sebagai 
adsorben pada proses produksi karoten pada fraksi olein minyak sawit kasar.

\section{METODE PENELITIAN}

\section{Bahan dan Alat}

Bahan yang digunakan dalam penelitian ini adalah minyak sawit kasar, $n$-Heksan, $\mathrm{HCl} 4 \mathrm{M}$, aquades, kulit kacang tanah, kertas saring.

Peralatan yang digunakan yaitu neraca analitik, penyaring buchner, mesin kocok, spektrofotometer UV-VIS, ayakan 120 mesh, blender, dan alat-alat gelas yang umum digunakan dalam Laboratorium Kimia.

\section{Prosedur Penelitian}

\section{Tahap Persiapan Minyak Sawit Kasar}

Minyak sawit kasar disaring menggunakan alat penyaring vakum dengan maksud memisahkan olein dan stearin. Cairan hasil penyaringan dinyatakan sebagai fraksi olein, sedangkan padatannya disebut fraksi stearin

\section{Preparasi Arang Aktif Kulit Kacang} Tanah (Saputro, 2010)

Kulit kacang tanah di cuci kemudian di keringkan. Selanjutnya kulit kacang tanah di tanur dengan suhu $450^{\circ} \mathrm{C}$ selama 90 menit, menghaluskan arang kulit kacang tanah sampai halus, mengayak arang kulit kacang tanah dengan ukuran ayakan 120 mesh, kemudian arang kulit kacang tanah di aktivasi.

\section{Aktivasi Arang dengan $\mathrm{HCl} 4 \mathrm{M}$}

Sebanyak 100 g serbuk arang direndam dalam reagen aktivator $\mathrm{HCl} 4 \mathrm{M}$ selama 24 jam, kemudian disaring dan dicuci dengan aquades. Arang yang telah dicuci, dikeringkan dalam oven pada suhu $110^{\circ} \mathrm{C}$ selama 3 jam. Selanjutnya arang didinginkan dalam desikator dan arang siap digunakan.

Pengaruh Rasio Adsorben/Olein (Hayuningtias, 2007)

Menyiapkan elenmenyer $250 \mathrm{ml}$ sebanyak 5 buah. Erlenmeyer selanjutnya diisi dengan arang kulit kacang tanah dan olein dengan perbandingan $1: 5,1,5: 5,2$ : 5, 2,5: 5 dan $3: 5$ b/v. Campuran selanjutnya dikocok menggunakan mesin kocok agitasi 250 rpm, selama 3 jam, kemudian campuran disaring menggunakan penyaring vakum. Padatan yang diperoleh diekstrak menggunakan pelarut heksan $50 \mathrm{ml}$ sebanyak 3 kali hingga pelarut tidak berwarna. Ekstrak selanjutnya dianalisis menggunakan metode spektrofotometri.

Analisis Karoten dari fraksi olein (Mappiratu, 1990)

Residu dari hasil pada perlakuan sebelumnya dianalisis kandungan karotennya dengan menggunakan metode spektrofotometer UV-VIS pada panjang gelombang $445 \mathrm{~nm}$. Kadar karoten dihitung menggunakan persamaan (Mappiratu, 1990).

$$
\mathrm{X}=\frac{\mathrm{A} \times \mathrm{Y}}{E_{1 \mathrm{~cm}{ }^{1 \%}} \boldsymbol{X 1 0 0}}
$$

Dimana :

$$
\begin{aligned}
& X=\text { Berat karoten dalam } \mathrm{g} \\
& \mathrm{A}=\text { Absorban } \\
& Y=\text { Volume larutan karoten }(\mathrm{ml}) \\
& E_{1 \mathrm{~cm}}{ }^{1 \%}=\text { Koefisien serapan } 2500 \mathrm{ml} / \mathrm{g}
\end{aligned}
$$




\section{HASIL DAN PEMBAHASAN}

\section{Rasio Adsorben terhadap Penyerapan Karoten}

Adsorben dari kulit kacang tanah digunakan untuk memproduksi karoten dari fraksi cair minyak sawit kasar. Kulit kacang tanah berpotensi sebagai adsorben karena mengandung selulosa yang cukup tinggi yaitu sebesar 63,5\% (Werdiono, 2006). Arang kulit kacang tanah perlu dihaluskan terlebih dahulu sebelum diaktivasi. Hal ini dilakukan untuk memperluas permukaan dan memperbesar jumlah pori arang kulit kacang tanah, selanjutnya dilakukan aktivasi menggunakan $\mathrm{HCl}$. Aktivasi dilakukan untuk memperluas pori-pori permukaan arang sehingga efisien untuk dijadikan adsorben. Menurut Pari (2004), larutan $\mathrm{HCl}$ dapat melarutkan tar, hidrokarbon dan pengotor-pengotor (mineral anorganik yang menutupi permukaan pori-pori arang) yang dihasilkan pada proses karbonasi serta dapat mengembangkan stuktur pori yang ada pada arang.

Analisis karoten pada fraksi olein minyak sawit kasar yang diekstrak menggunakan heksan dilakukan dengan menggunakan metode spektrofotometri UV - Vis pada panjang gelombang maksimum 445 nm. PORIM (1995) dalam Kuswardhani (2007) telah menguji bahwa karotenoid minyak sawit yang dilarutkan dalam heksan mempunyai serapan maksimum pada panjang gelombang 446 $\mathrm{nm}$. Kandungan karotenoid pada sampel diperoleh sebesar $0,74 \mathrm{mg}$.

Variasi rasio adsorben yang digunakan pada penelitian ini yaitu 1: 5 ; 1,5:5; $2: 5 ; 2,5: 5$ dan $3: 5$ (b/v) dan waktu kontak selama 3 jam dengan kecepatan pengocokkan $250 \mathrm{rpm}$. Peningkatan persen penyerapan karoten yang didasarkan pada perbedaan berat adsorben ditunjukkan dalam Gambar 1.

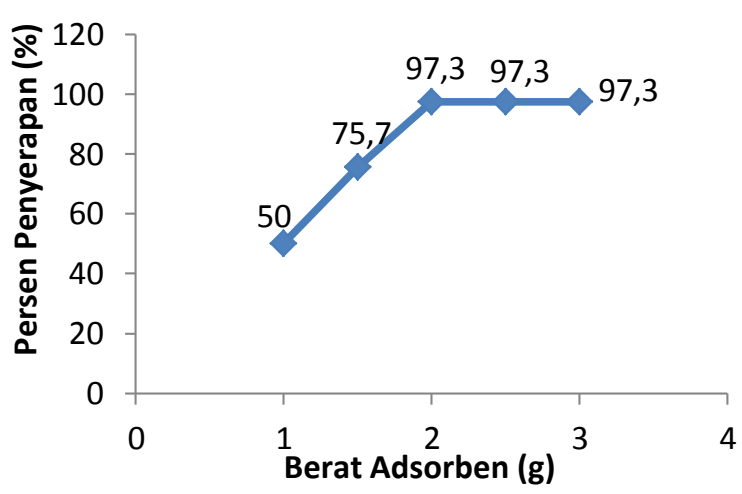

Gambar 1. Kurva hubungan antara rasio adsorben arang aktif terhadap persen penyerapan karoten

Berdasarkan Gambar 1, dapat diketahui bahwa nilai persen penyerapan karoten oleh adsorben semakin meningkat seiring dengan meningkatnya rasio adsorben. Peningkatan ini terjadi karena semakin berat adsorben maka ketersediaan permukaan aktif juga meningkat. Peningkatan jumlah permukaan aktif akan meningkatkan efisiensi penjerapan. Penyerapan karoten oleh adsorben mengalami titik maksimum pada rasio 2 : $5(\mathrm{~b} / \mathrm{v})$ dengan persen penyerapan mencapai $97,3 \%$, ketika berat adsorben ditingkatkan lagi, persen penyerapan karoten oleh adsorben 
konstan. Hal ini menunjukkan bahwa karoten pada olein telah habis.

Berdasarkan pengolahan data menggunakan SPSS 16.0 pada uji lanjut Duncan, perbedaan tiap kelompok dapat dilihat dari Homogeneous Subsets yang memperlihatkan apakah tiap kelompok berada dalam kolom subset yang sama atau kolom yang berbeda. Pada penelitian ini, hasil uji menunjukkan perlakuan variasi rasio $1: 5(\mathrm{~b} / \mathrm{v})$ dan 1,5: $5(\mathrm{~b} / \mathrm{v})$ berada pada kolom subset yang berbeda, yaitu kolom 1 dan kolom 2. Perbedaan penempatan rasio pada tiap kolom mengidentifikasikan adanya perbedaan yang signifikan pada setiap perlakuan atau berbeda nyata, namun rasio 2:5 (b/v), 2,5: $5(\mathrm{~b} / \mathrm{v})$ dan $3: 5(\mathrm{~b} / \mathrm{v})$ berada pada kolom yang sama, yaitu kolom 3. Hal ini menunjukkan bahwa perlakuan untuk rasio $2: 5,2,5: 5$ dan $3: 5$ (b/v) tidak memberikan perbedaan yang nyata atau dapat dikatakan bahwa perlakuan tersebut tidak memberikan pengaruh yang nyata terhadap perolehan karoten. Rasio adsorben terbaik diperoleh pada rasio 2 : 5 (b/v) dengan waktu pengocokkan 3 jam. Berat karoten yang diperoleh 0,72 mg. Kasimah (2008), memperoleh berat karoten sebesar 1,307 $\mathrm{mg}$ dengan menggunakan lempung $(2,5: 5 \mathrm{~b} / \mathrm{v})$ sebagai adsorben dan lama pengocokkan 3 jam. Hayuningtyas (2007) memperoleh $\beta$-karoten sebesar $375,50 \mu \mathrm{g} / \mathrm{ml}$ pada penggunaan bentonit $(1: 3 \mathrm{~b} / \mathrm{v})$ sebagai adsorben dan sebesar 426,791 $\mu \mathrm{g} / \mathrm{ml}$ pada arang aktif. Wulandari (2007), memperoleh karotenoid sebesar 317,2 $\mu \mathrm{g}$ melalui proses elusi dengan menggunakan adsorben abu sekam padi:silika gel (30: $10(\mathrm{~b} / \mathrm{b}))$.

\section{KESIMPULAN}

Berdasarkan hasil penelitian dan pembahasan, dapat disimpulkan bahwa rasio adsorben berpengaruh terhadap berat karoten, pada penelitian ini diperoleh rasio adsorben yang menghasilkan karoten tertinggi adalah 2:5 (b/v) dengan berat karoten yang diperoleh sebesar 0,72 mg selama 3 jam pengocokkan dan persen penyerapan mencapai $97,3 \%$.

\section{DAFTAR PUSTAKA}

Direktorat Jendral Perkebunan Indonesia. 2014. Produksi Kelapa Sawit Menurut Provinsi di Indonesia, (http://www.pertanian.go.id/IP ASEM BUN 2014/ Produksi-KelapaSawit.pdf), diakses pada tanggal 20 Februari 2016.

GAPKI. 2015. Refleksi Industri Kelapa Sawit 2014 dan Prospek 2015. (http://www.gapki.or.id/Page/PressR eleaseDetail?guid), diakses pada tanggal 6 Februari 2016

Hayuningtias. I. R. 2007. Kinetika Adsorpsi Isotermal $\beta$ - Karoten Dari Olein SawitKasar Dengan Menggunakan Bentonit. [Skripsi]. Bogor: Fakultas Teknologi Pertanian. IPB.

Iwasaki R., Murakoshi M. 1992. Palm oil yields carotene for word markets oleochemicals. Inform. 3(2): 210 217.

Kasimah. 2013. Penggunaan Lempung Sebagai Adsorben Dalam Produksi Karoten dari Fraksi Olein Minyak Sawit Kasar. [Skripsi]. Palu: Jurusan Kimia. Fakultas Matematika dan IImu Pengetahuan Alam. UNTAD.

Kuswardhani, D. S. 2007. Mempelajari Proses Pemekatan Karoten dari 
Minyak Sawit Kasar dengan Metode Fraksinasi Bertahap. [Skripsi]. Bogor: Fakultas Teknologi Pertanian. IPB.

Mappiratu. 1990. Produksi Beta Karoten Pada Limbah Cair Topioka Dengan Kapang Oncom Merah. [Tesis]. Bogor: FPS-Institut Pertanian Bogor.

May, C.Y. 1994. Palm Oil Carotenoids. Food and Nutrition Bulletin. 15 (2): 130-136.

Muhilal. 1991. Minyak sawit suatu produk nabati untuk penanggulangan atherosclerosis dan penundaan proses penuaan. Prosiding Seminar Nilai Tambah Minyak Kelapa Sawit untuk Meningkatkan Derajat Kesehatan. Jakarta.

Mustapa AN, Manan ZA, Mohd Azizi CY, Setianto WB, dan Mohd Omar. 2010. Extraction of $\beta$-carotenes from palm oil mesocarp using sub-critical R134a. J Food chemistry. 42:1-6.

Pari, G. 2004. Kajian Struktur Arang aktif dari Serbuk Gergaji Kayu Sebagai Adsorben Emisi Formaldehida Kayu Lapis. [Disertasi]. Bogor: Program Studi Ilmu Pengetahuan Kehutana dan Sekolah Pascasarjana IPB.

Saputro, M. 2010. Pembuatan karbon aktif dari kulit Kacang tanah (arachis hypogaea) dengan Aktivator Asam Sulfat. Laporan Tugas Akhir. Semarang: Program studi Diploma III Teknik Kimia. Program Diploma Fakultas Teknik. Universitas Diponegoro.

Werdiono D. 2006. Bahan Bakar Alternatif Mengubah Kulit Kacang Tanah Jadi Briket. (http://www2.kompas.com/ kompascetak/0712/06/jogja/1045515 .htm), diakses pada tanggal 7 Juni 2013.

Wulandari, N. 2007. Produksi Konsentrat Karotenoid dari Fraksi Cair Minyak Sawit Menggunakan Metode Kromatografi Kolom Adsorpsi. Jurnal IImu Pertanian Indonesia. 12 (1): 28 - 34. 